\title{
KEBIJ AKAN FORMULASI ASAS PERMAAFAN HAKIM DALAM UPAYA PEMBAHARUAN HUKUM PIDANA NASIONAL
}

\author{
Khilmatin Maulidah ${ }^{1 *}$, Nyoman Serikat Putra J aya ${ }^{2}$ \\ 1Program Studi Magister Ilmu Hukum, Fakultas Hukum, Universitas Diponegoro \\ 2Fakultas Hukum, Universitas Diponegoro \\ khilmatinmaulidah766@gmail.com
}

\begin{abstract}
The Criminal Code (KUHP) follows to the principle of formal legality so that it seems rigid and the law that lives in Indonesian society is as if it is not recognized as a source of law. This study aims to determine the policy formulation of the principle of forgiveness of judges in criminal law that is in force today, and analyze the policy of the principle of the forgiveness of judges in criminal law in the future. The research method used in this article is a normative juridical approach to the law and conceptual approach. The results of the research show that the Criminal Code does not currently regulate the problem of the judge's forgiveness, so that the criminal case that was tried must be given a criminal verdict even though the defendant's actions were very mild and not against the law materially. This requires an effort to reform the criminal law, which is to revive the law that lives in a society that seems to have been killed by colonial law by formulating the principle of apology for judges such as in the Netherlands which has regulated Article 9a of the Indonesian Penal Code.
\end{abstract}

\section{Keywords: Formulation Policy; J udicial Pardon; Penal Reform.}

\begin{abstract}
ABSTRAK
Kitab Undang-Undang Hukum Pidana (KUHP) menganut asas legalitas formil sehingga terkesan kaku dan hukum yang hidup di dalam masyarakat Indonesia seolah-olah tidak diakui sebagai sumber hukum. Penelitian ini bertujuan untuk mengetahui kebijakan formulasi asas permaafan hakim dalam hukum pidana yang berlaku saat ini, dan menganalisis kebijakan asas permaafan hakim dalam hukum pidana di masa yang akan datang. Metode penelitian yang digunakan dalam artikel ini adalah yuridis normatif dengan pendekatan perundangundang dan konseptual. Hasil penelitian menunjukkan bahwa KUHP saat ini tidak mengatur masalah permaafan hakim sehingga perkara pidana yang disidangkan harus dijatuhi putusan pidana meskipun perbuatan terdakwa sangat ringan dan tidak bersifat melawan hukum secara materiil. Hal ini yang memerlukan usaha pembaharuan hukum pidana yaitu menghidupkan kembali hukum yang hidup di masyarakat yang seolah-seolah dimatikan oleh hukum kolonial dengan merumuskan asas permaafan hakim seperti di negara Belanda yang sudah mengatur dalam Pasal 9a KUHP Belanda.
\end{abstract}

\section{Kata Kunci : Kebijakan Formulasi; Permaafan Hakim; Pembaharuan Hukum Pidana.}

\footnotetext{
${ }^{*}$ Corresponding Author
} 


\section{A. PENDAHULUAN}

Indonesia merupakan negara kesatuan yang berlandaskan Pancasila juga sebagai negara hukum sebagaimana tertuang dalam penjelasan UndangUndang Dasar Negara Republik Indonesia Tahun 1945 bahwa "Indonesia ialah negara yang berdasar atas hukum (Rechsstaat)". Kemudian dijelaskan lebih lanjut bahwa "Negara Indonesia berdasar atas hukum (Rechsstaat), tidak berdasar kekuasaan belaka (Machtstaat)." Konsep negara hukum di sini haruslah diartikan dan diimplementasikan selaras dengan nilai-nilai Pancasila sebab Pancasila merupakan sumber dari segala sumber hukum, yaitu hukum yang berketuhanan, berkemanusiaan, hukum yang beradab, berkeadilan, dan sebagainya (Rahardjo,2009).

Hukum positif di Indonesia sejak merdeka sampai saat ini masih berpedoman pada hukum warisan kolonial Belanda yang dikodifikasikan ke dalam Kitab Undang-Undang Hukum Pidana (KUHP), padahal dalam perkembangannya nilai-nilai dalam hukum Belanda sudah tidak sesuai dengan nilai-nilai masyarakat Indonesia. Inilah yang menjadi faktor bekerjanya hukum pidana di Indonesia terkesan sangat kaku, karena KUHP menganut asas legalitas formil yang hanya mengakui hukum tertulis saja, hukum yang hidup di dalam masyarakat Indonesia seolah-olah diabaikan dan tidak diakui sebagai sumber hukum. Hal inilah yang memerlukan usaha pembaharuan hukum pidana yaitu menghidupkan kembali hukum yang hidup di masyarakat yang seolah-seolah dimatikan oleh hukum kolonial.
Barda Nawawi Arief menyatakan, bahwa usaha pembaharuan hukum di Indonesia sudah dimulai sejak lahirnya UUD 1945 dan tidak dapat dilepaskan pula dari landasan dan sekaligus tujuan yang ingin dicapai seperti telah dirumuskan juga dalam Pembukaan UUD 1945. Tujuan yang dimaksud adalah "melindungi segenap bangsa Indonesia dan untuk memajukan kesejahteraan umum berdasarkan Pancasila". Garis kebijakan umum inilah sebagai landasan dan tujuan politik hukum di Indonesia sekaligus menjadi landasan serta tujuan dari setiap usaha pembaharuan hukum, termasuk pembaharuan di bidang hukum pidana dan kebijakan penanggulangan kejahatan di Indonesia (Maerani,2015).

Hukum pidana yang terkesan bersifat kaku dan lebih mengedepankan segi formalitas menimbulkan pandangan bahwa hukum pidana diformulasikan dan ditegakkan dengan tujuan untuk memberikan pembalasan. Sebagaimana pidana penjara yang terkesan sebagai alat pembalasan yang tercantum dalam Pasal 10 KUHP. Bertolak dari pandangan demikian maka aparat penegak hukum cenderung selalu mengkualifikasikan suatu perbuatan sebagai tindak pidana apabila telah memenuhi rumusan pasal dalam KUHP saja dan harus diselesaikan melalui jalur hukum pidana yang kemudian berujung pada putusan pidana penjara.

Diakui atau tidak diakui, di kalangan praktisi hukum masih ada persepsi bahwa pidana merupakan satu-satunya reaksi paling tepat atas perilaku yang dianggap anti sosial. Kepada mereka yang 
perbuatannya memenuhi rumusan delik harus dikenai dengan pidana (Gunarto, 2009).

Hukum pidana tidak boleh hanya berorientasi pada perbuatan manusia saja (daad strafrecht) sebab dengan demikian hukum pidana menjadi tidak manusiawi dan mengutamakan pembalasan. Sebaliknya hukum pidana juga tidak benar apabila hanya memperhatikan si pelaku saja (daderstrafrecht), sebab dengan demikian penerapan hukum pidana akan berkesan memanjakan penjahat dan kurang memperhatikan kepentingan yang luas, yaitu kepentingan masyarakat, kepentingan negara, dan kepentingan korban tindak pidana (Soponyono,2012).

Sebagai contoh yaitu kasus Nenek Minah yang dituduh mencuri 3 biji kakao yang kemudian dihukum pidana percobaan 1 bulan 15 hari, kasus pencurian kapuk randu oleh Manisih dan anggota keluarganya dipidana penjara selama 24 hari, kasus Basar dan Cholil yang dituduh mencuri buah semangka. Semua perbuatan dalam kasus tersebut dikualifikasikan sebagai tindak pidana pencurian semata-mata hanya dilihat bahwa perbuatan tersebut memenuhi rumusan pasal 362 KUHP. Fenomena ini membuktikan bahwa hukum pidana di Indonesia sangatlah kaku sehingga mengenyampingkan kebenaran materiil atau fakta yang sesungguhnya dibalik perbuatan yang didakwakan.

Sebagaimana diungkapkan oleh Hakim yang memutus perkara Mbah Minah, yaitu Hakim Bambang. Beliau menyatakan bahwa kasus seperti yang melibatkan Mbah Minah tidak semestinya sampai disidangkan di pengadilan. Karena kasus tersebut merupakan kasus sederhana atau kasus ringan (Wibawa, 2017).

KUHP tidak secara eksplisit mengatur mengenai pengertian tindak pidana ringan, oleh karena itu dapat ditemukan di dalam Peraturan Mahkamah Agung Republik Indonesia (PERMA) No.2 Tahun 2012 Tentang Penyesuaian Batasan Tindak Pidana Ringan dan Jumlah Denda dalam KUHP diatur bahwa perbuatan pencurian yang merugikan seseorang di bawah Rp. 2.500.000,00 dikualifikasikan sebagai tindak pidana ringan. Di dalam peraturan tersebut pidana yang dapat dikenakan adalah pidana denda, pembayaran ganti kerja di pelayanan umum, dan sebagainya. Namun demikian, PERMA No.2 Tahun 2012 tersebut hanya mengatur mengenai penyesuaian batasan nilai kerugian dan ganti rugi tindak pidana ringan, salah satu contohnya adalah pencurian ringan. Tidak serta merta dapat menghapuskan sanksi pidana atau mengubah jenis sanksi pidana yang dapat diterapkan atasnya, karena mengenai sanksi pidana itu sendiri sudah ditentukan dalam Pasal 10 Kitab UndangUndang Hukum Pidana (KUHP) (Pratiwi, 2015).

Bertolak dari PERMA No. 2 Tahun 2012 maka kasus-kasus seperti Nenek Minah, Kasus Basar dan Cholil, tidak seharusnya sampai ke "meja hijau" karena nilai kerugiannya sangat kecil/ringan, bahkan menurut pengakuan "pelaku" bahwa perbuatan yang dilakukannya merupakan perbuatan yang diperbolehkan oleh penduduk setempat, dapat dikatakan sebagai hukum kebiasaan masyarakat 
setempat. Jika masyarakat setempat mengatakan demikian maka seharusnya kasus tersebut bukanlah delik atau tindak pidana dan tidak sepatutnya dipidana.

Hal ini menjadi ironi karena dalam beberapa kasus-kasus mereka tetap dinyatakan bersalah dan dijatuhi pidana oleh hakim. Indonesia sebagai negara yang mempunyai Pancasila justru pada praktiknya tidak secara penuh mengamalkan sila-sila yang tercantum dalam Pancasila, seolah-olah seseorang yang terbukti memenuhi rumusan undang-undang secara langsung dapat dinyatakan bersalah dan harus dipidana, terkesan tidak adanya aturan yang menegasikan sifat melawan hukumnya perbuatan (secara formal), dan seolah-olah tidak mencerminkan asas demokrasi, asas kemasyarakatan, asas kemanusiaan, asas keadilan sosial juga asas ketuhanan.

Lebih ironi lagi ketika melihat KUHP WvS Belanda yang merupakan KUHP yang berlaku di Indonesia saat ini, justru mencantumkan pasal sisipan yaitu Pasal 9a yang mencerminkan asas kemanusiaan dengan mengatur tentang asas permaafan hakim (Rechterlijk Pardon). Asas tersebut memungkinkan hakim untuk memaafkan perbuatan terdakwa dan tidak menjatuhi pidana kepadanya. Asas ini menunjukkan sifat fleksibel yang terdapat dalam KUHP Belanda. Sebagai sebuah sistem, hal ini menjadi salah satu faktor yang menimbulkan lembaga pemasyarakatan menjadi over capacity. Sebab aturan yang menjadi pedoman bagi hakim terkesan mengahraruskan seorang terdakwa diajtuhi pidana.

Bertolak dari uraian latar belakang dalam penulisan ini terkait dengan kebijakan formulasi asas permaafan hakim dalam upaya pembaharuan hukum pidana nasional menjadi masalah pada pembahasan ini dikarenakan belum adanya pasal yang mengatur secara eksplisit mengenai kewenangan hakim untuk memaafkan perbuatan yang dilakukan oleh terdakwa. Sehingga KUHP yang berlaku saat ini terkesan 'kaku' dan pada akhirnya mencederai rasa keadilan masyarakat. Hal ini merupakan masalah mendasar dari KUHP yang berlaku saat ini.

Kerangka teori yang digunakan yaitu mengacu pada teori yang dikemukakan oleh Prof.Barda Nawawi bahwa pidana dapat dijatuhkan jika memuat syarat adanya tindak pidana dan kesalahan / PJP (Pertanggungjawaban Pidana). Dalam formula / model / pola / konvensional tersebut, tidak terlihat variable "tujuan", karena tidak dirumuskan secara eksplisit dalam KUHP, sehingga terkesan "tujuan" berada di luar sistem. Dengan model demikian, seolah-olah dasar pembenaran atau justifikasi adanya pidana hanya terletak pada TP (syarat objektif) dan Kesalahan (syarat subjektif). Jadi seolah-olah pidana dipandang sebagai konsekuensi absolut yang harus ada, apabila kedua syarat itu terbukti. Jelas terkesan sebagai "model kepastian" yang kaku. Dirasakan janggal (menurut model ini), apabila kedua syarat itu terbukti tetapi si pelaku "dimaafkan" dan tidak dipidana. Dengan demikian ide "permaafan/pengampunan hakim" (Rechterlijk 
pardon/judicial pardon/dispensa de pena) seolaholah tidak mempunyai tempat atau setidak-tidaknya sulit diterima (Arief, 2017).

Prof.Moeljatno mengungkapan dalam pidato dies natalis, beliau memberi arti kepada "perbuatan pidana" sebagai "perbuatan yang diancam dengan pidana, barangsiapa melanggar larangan tersebut". Untuk adanya perbuatan pidana harus ada unsurunsur: 1). Perbuatan (manusia); 2). Yang memenuhi rumusan dalam undang-undang (ini merupakan syarat formil); dan 3). Bersifat melawan hukum (ini merupakan syarat materiil). Syarat formil itu harus ada, karena adanya azas legalitas yang terimpul dalam Pasal 1 KUHP. Syarat materiil itu harus pula ada, karena perbuatan itu harus pula betul-betul dirasakan oleh masyarakat sebagai perbuatan yang tak boleh atau tak patut dilakukan (Sudarto, 2009)

Berdasarkan penjelasan teori dari pakar diatas yang kemudian dijadikan sebagai landasan teori pada pembahasan, penulis akan menguraikan mengenai Kebijakan Formulasi Asas Permaafan Hakim Dalam Upaya Pembaharuan Hukum Pidana Nasional.

Gap Analysis dan Permasalahan dalam penulisan ini yaitu KUHP tidak mengatur secara eksplisit dan jelas mengenai asas permaafan hakim sehingga kasus-kasus yang kerugiannya sangat kecil/ringan dan tidak signifikan tetap dijatuhi putusan pidana oleh hakim. Meskipun pidana yang dijatuhkan ringan, tetapi hal itu tetap menjadi ironi karena seseorang tetap dinyatakan bersalah di depan persidangan sehingga tetap melukai nurani seseorang yang bersangkutan maupun masyarakat secara umum. Seyogyanya Indonesia sebagai negara yang berlandaskan Pancasila mengimplementasikan asas kemanusiaan yang diwujudkan dalam asas permaafan hakim. Hal ini lah yang memerlukan upaya pembaharuan hukum pidana dalam hal kebijakan formulasi asas permaafan hakim.

Bertolak dari Gap Analysis tersebut di atas maka rumusan masalah dalam peneltian ini adalah sebagai berikut:

1. Bagaimana kebijakan formulasi asas permaafan hakim dalam kebijakan hukum pidana yang berlaku saat ini?

2. Bagaimana kebijakan formulasi asas permaafan hakim dalam kebijakan hukum pidana di masa yang akan datang?

Permasalahan akan diuraikan dalam bagian pembahasan selanjutnya. Terkait dengan penelitian ini, sebelumnya telah ada yang melakukan penelitian yang pada pokoknya berfokus pada kebijakan formulasi dan aplikasi nilai permaafan hakim dalam peradilan pidana di Indonesia (Barlian, \& Arief, 2019). Penelitian yang kedua berfokus pada rechterlijk pardon atau permaafan hakim dilihat secara konseptual, filosofis, dan historis kaitannya dengan rancangan KUHP (Saputro, 2016). Penelitian yang ketiga berfokus pada konsep Judicial Pardon (Permaafan Hakim) dalam masyarakat adat di Indonesia (Farikhah, 2016).

Penelitian selanjutnya yang dibuat dalam bentuk jurnal internasional yaitu (Sudira, 2014). "The 
Construction of Penal Mediation Model in Handling Family Negclect Cases in the Future", didalamnya membahas tentang konsep permaafan hakim tetapi lebih fokus kepada konsep mediasi penal. Penelitian berikutnya berfokus pada nilai permaafan hakim dikaitkan dengan hukum islam (Wahyuningsih, \& Hafidz, 2017).

Berdasarkan penelitian sebelumnya terdapat perbedaan yang menunjukan kebaruan dalam penelitian ini yaitu penulis tidak hanya membahas dalam konteks kebijakan hukum pidana yang berlaku saat ini tetapi juga dengan menggunakan kajian perbandingan dengan negara lain yaitu membandingkan kebijakan hukum pidana di Indonesia dengan Belanda. Tujuan dari penulisan ini yaitu untuk mengetahui dan menganalisis kebijakan formulasi asas permaafan hakim dalam hukum pidana yang berlaku saat ini, dan untuk mengetahui serta menganalisis kebijakan formulasi asas perrmaafan hakim yang sebaiknya dirumuskan di masa yang akan datang dengan membandingkan aturan pidana di Indonesia dengan Belanda.

Berdasarkan uraian latar belakang permasalahan di atas maka judul yang diangkat adalah sebagai berikut: KEBIJ AKAN FORMULASI ASAS PERMAAFAN HAKIM DALAM UPAYA PEMBAHARUAN HUKUM PIDANA NASIONAL.

\section{B. METODE PENELITIAN}

Penelitian tentang kebijakan formulasi asas permaafan hakim dalam upaya pembaharuan hukum pidana nasional ini menggunakan metode pendekatan yang bersifat yuridis normatif, yaitu dengan mengkaj/menganalisis data sekunder yang berupa bahan-bahan hukum terutama bahan hukum primer dan bahan hukum sekunder. Adanya pendekatan perbandingan hukum diperlukan untuk memberikan gambaran dan masukan bagi kebijakan hukum pidana yang sebaiknya dirumuskan di masa yang akan datang.

Spesifikasi dalam penelitian ini adalah penelitian deskriptif analitis. Jenis dan teknik pengumpulan data dalam penelitian hukum diperoleh melalui studi kepustakaan. Metode analisis data yang digunakan dalam penelitian ini adalah analisis kualitatif.

\section{HASIL DAN PEMBAHASAN}

1. Kebijakan Formulasi Asas Permaafan Hakim

\section{Dalam Hukum Pidana yang Berlaku saat ini}

Pembaharuan hukum pidana pada tataran regulasi telah diupayakan oleh lembaga pembentuk undang-undang sejak tahun 1963, dengan disusunnya Rancangan Kitab Undang-Undang Hukum Pidana (selanjutnya disebut RUU KUHP). Namun sampai saat ini, pemerintah belum juga berhasil membuat kodifikasi peraturan induk hukum pidana yang didasarkan nilai-nilai yang ada di dalam Pancasila serta Pembukaan UUD 1945. Konsekuensi dari belum disahkannya RUU KUHP adalah Negara Indonesia tetap menggunakan Kitab Undang-Undang Hukum Pidana (KUHP) peninggalan pemerintah Hindia-Belanda yang tentunya telah tertinggal oleh 
kemajuan yang terjadi dalam kehidupan masyarakat. (Yosuki, \& Tawang, 2018).

Penyusunan konsep KUHP baru bertujuan menggantikan KUHP/WvS karena ide/konsep dasar permikiran, nilai filosofi dalam penyusunannya sudah tidak sesuai lagi dengan ide/konsep dasar pemikiran dan nilai filosofi disusunnya konsep. Ide/konsep dasar pemikiran dan nilai filosofi disusunnya konsep adalah Pancasila yang jalinan nilai dalam setiap sialnya mencerminkan "ide keseimbangan" (Maerani, 2015). Ide dasar keseimbangan ini merupakan pilihan hukum yang bisa disebut memiliki konsep prismatik (nilai keseimbangan yang baik). Mengingat ide dasar keseimbangan mengidentifikasi pilihan kombinatif atas nilai-nilai yang ada di tengah masyarakat Indonesia (Faisal, 2014).

KUHP yang berlaku saat ini pada dasarnya tidak mengatur mengenai asas permaafan hakim atau rechterlijk pardon karena KUHP yang merupakan produk dari Belanda memiliki latar belakang nilai individualism dan liberalism sehingga kebutuhan dan kepentingan masing-masing individu bukan menjadi prioritas melainkan mengutamakan kepentingan bersama. Seseorang mendapatkan keadilan atau tidak bukanlah menjadi persoalan, yang dilihat hanyalah seseorang telah melakukan suatu perbuatan yang memenuhi rumusan delik dalam undang-undang maka seseorang tersbebut dinyatakan bersalah dan harus dipidana.

Sebagaimana diungkapkan oleh Barda Nawawi Arief bahwa kebijakan formulasi dalam perumusan sistem pemidanaan materiil di Indonesia pada saat ini yaitu Kitab Undang-Undang Hukum Pidana (KUHP)/Wetboek van Strafrecht (WvS) berasal dari warisan jajahan Belanda yang penyusunannya lebih berorientasi kepada pelaku tindak pidana. Nilai filosofis yang menjadi latar belakang disusunnya KUHP/WvS adalah individualism dan liberalism yang dilandasi oleh aliran klasik/neo klasik yang lebih berorientasi pada perbuatan dan pelaku tindak pidana, padahal dalam tujuan nasional (national goals) yang merupakan garis kebijakan umum yang menjadi landasan dan sekaligus tujuan pencapaian politik hukum di Indonesia, ada dua tujuan yang ingin dicapai oleh hukum pidana yaitu "perlindungan masyarakat" dan "kesejahteraan masyarakat". Kedua tujuan tersebut sebagai batu landasan (acornerstone) dari hukum pidana dan pembaruan hukum pidana (Arief, 2009).

Kekakuan dari KUHP dengan tidak mengatur asas permaafan hakim menimbulkan kesan bahwa hukum pidana bertujuan untuk memberikan pembalasan, seolah-olah seseorang yang bersalah menurut undang-undang tidak bisa dimaafkan. Jika dikaitkan dengan nilai-nilai dalam Pancasila sesuai dengan sila ke-1, sebagai contoh dalam kasus-kasus yang nilai kerugiannya kecil untuk tidak melanjutkan perkaranya melalui proses hukum atau memberi maaf terhadap sesama adalah sesuai tuntunan agama islam dan sebuah keutamaan, dengan berpedoman pada surat At-Taghabun ayat 14 : "dan jika kalian memaafkan dan tidak memarahi serta mengampuni (mereka) maka sesungguhnya Allah 
Jurnal Pembangunan Hukum Indonesia

Volume 1, Nomor 3, Tahun 2019
Program Studi Magister Ilmu Hukum Fakultas Hukum Universitas Diponegoro
Maha Pengampun lagi Maha Penyayang" (Fatoni,2015).

Mengenai tujuan pemidanaan pun sebetulnya belum diatur secara tegas di dalam KUHP yang berlaku saat ini. Apabila ingin mengetahui tujuan pemidanaan dalam KUHP, salah satunya dengan mempelajari historitas dari KUHP tersebut, terutama di negeri Belanda (Anugrah, 2019).

Mengingat tujuan pemidanaan maka dalam kondisi tertentu hakim tetap diberi kewenangan untuk memberi maaf dan tidak menjatuhkan pidana atau tindakan apapun, walaupun "tindak pidana" dan "kesalahan" telah terbukti. Dengan demikian, dapat dikatakan bahwa secara konseptual telah ada pergeseran yang sebelumnya bersifat kakulabsolut berubah menjadi model keseimbangan yang fleksibel (Gunarto,2012).

Tujuan pemidanaan tidak dirumuskan secara eksplisit dalam KUHP, sehingga terkesan tujuan berada diluar sistem. Dengan model demikian, seolah-olah dasar pembenaran adanya pidana hanya terletak pada tindak pidana dan kesalahan, oleh karena itu seolah-olah pemidanaan dianggap sebagai konsekuensi absolut yang harus ada, apabila kedua syarat ini terbukti. Kerangka berpikir seperti ini memberikan suatu legitimasi bahwa KUHP saat ini bersifat kaku (Yosuki, \& Tawang, 2018).

2. Kebijakan Formulasi Asas Permaafan Hakim Dalam Hukum Pidana yang Sebaiknya Dirumuskan di Masa yang Akan Datang
Penelitian ini akan memfokuskan pada substansi hukum di mana pembaharuan hukum pidana yang dilakukan adalah memunculkan asas permaafan hakim (Rechterlijk Pardon) ke dalam RUU KUHP. Menurut Barda Nawawi Arief, dalam tataran sistem kebijakan hukum pidana, tahap merumuskan atau memformulasikan suatu perundang-undangan hukum pidana adalah tahap yang paling strategis karena tahap formulasi adalah penegakan hukum secara abstrak . kesalahan pada tahap formulasi akan berakibat fatal pada tahap penegakan hukum selanjutnya yaitu penegakan hukum secara nyata (in concreto) (Tapiansari, \& Susanto, 2017).

Dalam kebijakan formulasi/kebijakan legislatif inilah diharapkan nilai-nilai sentral masyarakat yang hidup dan tumbuh di dalam masyarakat dapat terakomodasi sehingga hukum yang akan datang atau hukum yang dicita-citakan itu dapat berlaku efektif di masyarakat (Kusuma, 2016).

Pembaharuan Hukum Pidana pada hakikatnya mengandung makna, suatu upaya untuk melakukan reorientasi dan reformasi hukum pidana yang melandasi kebijakan sosial, kebijakan kriminal dan kebijakan penegakan hukum di Indonesia (Arief, 2014).

KUHP yang berlaku saat ini memang tidak mengatur masalah asas permaafan hakim, sehingga perlu dirumuskan dalam KUHP di masa yang akan datang. Sebab asas permaafan hakim akan mencerminkan asas kemanusiaan pada falsafah bangsa yaitu Pancasila, dan akan mengubah paradigma KUHP yang kaku menjadi fleksibel serta 
sebagai suatu sistem yang integral, maka pembaharuan hukum pidana materiil ini akan bermuara pada hukum pelaksanaan pidana yaitu dengan adanya asas permaafan hakim akan menjadi solusi untuk mengatasi persoalan over capacity pada lembaga pemasyarakatan yang selama ini menjadi masalah di Indonesia.

Asas permaafan hakim atau Rechterlijk Pardon saat ini berada pada tahapan formulasi RUU KUHP, yaitu diatur dalam Pasal 55 dan Pasal 56 RUU KUHP. Konsep permaafan hakim sebetulnya telah lama dilakukan dan tersebar di berbagai wilayah Indonesia. Konsep ini muncul dalam berbagai bentuk pelaksanaan di dalam masyarakat Indonesia, dimana dapat disimpulkan bahwa permaafan yang ada dalam masyarakat adat tidak serta merta menghapus pidana, tetap ada sanski yang diberikan namun sanksi tersebut tidak hanya untuk kepentingan korban dan pelaku namun juga untuk mengembalikan keseimbangan yang telah rusak akibat adanya tindak pidana (Farikhah, 2016).

Perkembangan RKUHP sampai saat ini yaitu RKUHP Juni 2019 belum kunjung disahkan. Padahal di dalamnya dirumuskan konsep tentang permaafan yang tercantum dalam Pasal 55 dan Pasal 56. Dalam Pasal 56 Ayat (2) RUU KUHP dikatakan bahwa ringannya perbuatan, keadaan pribadi, keadaan saat terjadi tindak pidana atau yang terjadi kemudian, dapat dijadikan pertimbangan hakim untuk tidak menjatuhkan pidana atau mengenakan tindakan dengan mempertimbangkan segi keadilan dan kemanusiaan. Hal ini berkaitan erat dengan sistem pemidanaan, di mana dengan adanya konsepsi Rechterlijk Pardon (Permaafan Hakim), maka hakim dalam menjustifikasi pemidanaan terhadap seseorang, hakim harus mempertimbangkan tindak pidana, kesalahan serta tujuan dan pedoman pemidanaan. Apabila hakim memandang bahwa orang tersebut tidak harus dijatuhkan pidana, maka hakim memberi maaf kepada pelaku tindak pidana (Yosuki, \& Tawang, 2018).

Sebagai bentuk pengampunan, maka dengan adanya permaafan seseorang yang bersalah tidak perlu dijatuhi hukuman atau meraskaan hukuman. Ketentuan seperti ini pada dasarnya hampir mirip dalam ketentuan pidana bersyarat (voorwaardelijke veroordeling) yang diatur dalam Pasal 14a-14f KUHP (Mukhtarzain, 2015).

Dalam melakukan usaha pembaharuan hukum pidana diperlukan kajian perbandingan hukum pidana dengan negara lain. Dalam penelitian ini akan membandingkan dengan KUHP Belanda. Rumusan yang tercantum dalam Pasal 9a KUHP Belanda mengatur tentang asas permaafan hakim atau Rechterlijk Pardon, berikut ini bunyi Pasal 9a KUHP Belanda :

"the judge may determine in the judgement that no punishment or measure shall be imposed, where he deems this advisable, by reason of the lack of gravity of the offense, the character of the offender, or the circumtances attendant upon the commission of the offense or there after".

Dari rumusan pasal di atas terlihat jelas bahwa hakim dapat tidak menjatuhkan putusan pidana maupun tindakan dengan memperhatikan berat 
ringannya perbuatan, karakter pelaku, keadaan yang terjadi saat perbuatan dilakukan maupun setelahnya.

Perbuatan yang sangat ringan/tidak signifikan tidak dijatuhi pidana, sebagaimana dikemukakan oleh I Ketut Sudira dalam artikelnya "One modern influence in criminal law is a principle known as subsosialitas (Subsocialitet) meaning if a conduct is a delict but socially has a little significance, it is not necessary to involve punishment or further legal action. As we can see from the Article 9 of the Dutch Criminal Code" (Sudira,2014).

Rumuan Pasal 9a tersebut di atas merupakan pedoman pemidanaan bagi hakim dalam menjatuhkan putusan agar supaya putusan berorientasi pada nilai kemanusiaan dan keadilan yaitu denganmempertimbangkan berat ringannya perbuatan, kepribadian pelaku, keadaan-keadaan pada saat perbuatan dilakukan maupun sesudahnya.

Di Belanda saat ini, 60\% (enam puluh persen) perkara pidana tidak lagi diselesaikan oleh Pengadilan, melainkan oleh Jaksa Penuntut Umum di luar pengadilan, di Belanda dikenal dengan istilah afdoening buiten process (penyelesaian perkara di luar pengadilan). Perkara yang ringan diselesaikan di luar pengadilan, perkara ringan yang dimaksud adalah tindak pidana yang diancam dengan pidana penjara di bawah 6 (enam) tahun ke bawah dengan cara ganti kerugian oleh pelaku tindak pidana kepada korban. Bentuk lain, apabila perkara ringan tetap diselesaikan di pengadilan, maka hakim dapat memutus dengan Rechterlijk pardon (permaafan hakim) dengan memperhatikan ringannya perbuatan, keadaan pelaku tindak pidana dan keadaan sebelum atau setelah tindak pidana itu dilakukan (Yosuki, \& Tawang, 2018).

Bahkan di Belanda ada kecenderungan menurunnya penggunaan atau penerapan pidana penjara, terlihat pada praktek pengadilannya terdapat suatu ketidaksukaan yang semakin besar terhadap pidana perampasan kemerdekaan dan pidana denda (Kholiq, Arief, \& Soponyono,2015).

Bertolak dari penjelasan di atas tentang aturan Rechterlijk Pardon pada KUHP Belanda terlihat hampir sama dengan rumusan Pasal 56 RKUHP, perbedaannya terletak pada adanya pertimbangan dari segi keadilan dan kemanusiaan dalam RKUHP.

Menjadi suatu ironi karena KUHP yang berlaku di Indonesia saat ini justru tidak mengatur asas permaafan hakim, baru diformulasikan dalam konsep KUHP yang sampai saat ini juga belum disahkan. Sehingga pada kasus-kasus yang tidak signifikan atau terlalu sepele seperti kasus Nenek Minah tetap dijatuhi putusan pidana oleh hakim. Apabila RKUHP segera disahkan dan tetap mencantumkan asas permaafan hakim, maka kasus-kasus seperti kasus nenek Minah dapat diberikan permaafan oleh hakim dan tidak hanya menegakkan asas kepastian, tetapi juga kemanusiaan dan keadilan. 


\section{SIMPULAN}

Berdasarkan pembahasan yang telah diuraikan di atas, maka dapat ditarik kesimpulan sebagai berikut:

KUHP yang berlaku saat ini pada dasarnya tidak mengatur mengenai asas permaafan hakim atau rechterlijk pardon sehingga apabila terjadi kasus-kasus sepele yang perbuatannya sangat ringan/sangat kecil/tidak signifikan maka hakim selalu menjatuhkan putusan pidana. Seolah-olah tidak ada pilihan lain yang dapat memberikan ruang bagi hakim untuk memaafkan terdakwa. Sebab hakim hanya berpedoman pada KUHP yang sangat kaku yang merumuskan suatu tindak pidana semata-mata hanya jika telah memenuhi rumusan pasal dalam undang-undang.

Ironinya, ketika KUHP yang berlaku saat ini merupakan warisan kolonial Belanda yang tidak mengatur tentang asas permaafan hakim, di Belanda telah memasukkan Pasal 9a yang mengatur masalah permaafan hakim sehingga pembaharuan kebijakan formulasi dalam hal ini perlu diupayakan. Dalam hal ini aturan Rechterlijk Pardon pada KUHP Belanda terlihat hampir sama dengan rumusan Pasal 56 RKUHP, perbedaannya terletak pada adanya pertimbangan dari segi keadilan dan kemanusiaan dalam RKUHP. Perumusan konsep rechterlijk pardon merupakan konsep yang sesuai dengan nilai-nilai yang hidup dalam masyarakat Indonesia dan selaras dengan tujuan pemidanaan yang dirumuskan dalam RKUHP.

\section{DAFTAR PUSTAKA}

\section{BUKU}

Arief, Barda N. (2009). Tujuan dan Pedoman Pemidanaan. Semarang: Badan Penerbit Universitas Diponegoro.

Arief, Barda N. (2014). Bunga Rampai Kebijakan Hukum Pidana: Perkembangan Penyusunan Konsep KUHP baru. Jakarta: Kencana Prenamedia Group.

Arief, Barda N. (2017). RUU KUHP Baru (Sebuah Restrukturisasi/Rekonstruksi Sistem Hukum Pidana Indonesia). Semarang: Badan Penerbit Universitas Diponegoro.

Rahardjo, S. (2009). Negara Hukum Yang Membahagiakan Rakyatnya. Yogyakarta: Genta Publishing.

Sudarto. (2009). Hukum Pidana I Edisi Revisi. Semarang: Penerbit Yayasan Sudarto.

\section{TESIS}

Pratiwi Nur, M. (2015). Putusan Pemberian Maaf Dalam Tindak Pidana Pencurian (Studi Kasus Putusan Hakim Di Persidangan Negeri Solok). Universitas Islam Indonesia.

\section{JURNAL}

Anugrah, R. (2019). Permaafan korban ditinjau dari tujuan pemidanaan dalam pembaharuan hukum pidana di indoensia, J urnal IImu Hukum Fakultas Hukum Universitas Riau, Vol. 8, (No.1), pp. 20-35. 
Barlian, Aristo Evandy A., \& Arief, Barda Nawawi. (2017). Formulasi Ide Permaafan Hakim (Rechterlijk Pardon) Dalam Pembaharuan Sistem Pemidanaan Di Indonesia. J urnal Law Reform, Vol.13, (No.1), pp. 28-44.

Tapiansari, Gialdah., \& Susanto, Anthon F. (2017).

Pola Penegakan Hukum Pidana Berdasarkan Nilai-Nilai Kemanusiaan Dalam Perspektif Asas Manfaat. J urnal Litigasi, Vol.1, (No.18), pp. 41-86.

Faisal. (2014). Membangun Politik Hukum Asas Legalitas Dalam Sistem Hukum Pidana Indonesia. Jurnal Hukum lus Quia lustum, Vol.21, (No.1), pp. 81- 95.

Fatoni, S. (2015). Pembaharuan Hukum Pidana Melalui Aktualisasi Nilai-Nilai Pancasila Berorientasikan Pendekatan Religius. Jurnal Hukum Islam IAIN Tulungagung, Vol.3, (No.1), pp.43-66.

Farikhah, M. (2016). Konsep Judicial Pardon (Permaafan Hakim) dalam Masyarakat Adat di Indonesia. Jurnal Media Hukum, Vol.25, (No.1), pp.81-92.

Gunarto, Marcus P. (2009). Sikap Memidana yang Berorientasi Pada Tujuan Pemidanaan, Jurnal Mimbar Hukum, Vol.21, (No.1), pp.93-108.

Gunarto, Marcus P. (2012). Asas Keseimbangan dalam Konsep Rancangan Undang-Undang Kitab Undang-Undang Hukum Pidana. J urnal Mimbar Hukum, Vol.24, (No.1), pp.1-186.
Kholiq, Abdul,. Arief, Barda Nawawi,. \& Soponyono, Eko. (2015). Pidana Penjara Terbatas:Sebuah Gagasan dan Reorientasi Terhadap Kebijakan Formulasi Jenis Sanksi Hukum Pidana Di Indonesia. Jurnal Law Reform, Vol.11, (No.1), pp. 100-112.

Kusuma, Jauhari D. (2016). Tujuan Dan Pedoman Pemidanaan Dalam Pembaharuan Sistem Pemidanaan di Indonesia. Jurnal Muhakkamah, Vol.1, (No.2), pp. 94-109.

Maerani, Ira A. (2015). Implementasi Ide Keseimbangan Dalam Pembangunan Hukum Pidana Indonesia Berbasis Nilai-Nilai Keadilan. J urnal Pembaharuan Hukum, Vol.2, (No.2), pp. 329-338.

Mukhtarzain, Abdullah A. (2018). Permaafan Dalam Pemidanaan Menurut Hukum Islam Dan Hukum Nasional. Jurnal Idea Hukum, Vol.4, (No.1), pp. 936-959.

Saputro, Adery A. (2016). Konsepsi Rechterlijk Pardon Atau Permaafan Hakim dalam Rancangan KUHP. Jurnal Mimbar Hukum, Vol.28, (No.1), pp. 61-76.

Sudira, I Ketut. (2014). The Construction of Penal Mediation Model in Handling Family Negclect Cases in the Future. International J ournal of Education and Research, Vol.2, (No.8), pp.429-438.

Soponyono, E. (2012). Kebijakan Perumusan Sistem Pemidanaan yang Berorientasi Pada Korban. Jurnal Masalah-Masalah Hukum, Jilid 41, (No.1), pp. 29-41. 
Jurnal Pembangunan Hukum Indonesia

Volume 1, Nomor 3, Tahun 2019

Wahyuningsih, Sri Endah., \& Hafidz, Jawade. (2017).

The Development of the Indonesian Criminal Code Derived From The Yudicial Pardon Value in Islamic Law. Jurnal Addin, Vol.11, (No.2), pp.295-320.

Wibawa, I. (2017). Implementasi Asas Kepastian Hukum Yang Berkeadilan Berdasar Cita Hukum Bangsa Indonesia (Kajian Putusan Pengadilan Negeri Banyumas tentang Kasus Mbah Minah). J urnal Yudisia. Vol.8, (No.1), pp. 18-44.

Yosuki, Aska., \& Tawang, Dian Adriawan Daeng. (2018). Kebijakan Formulasi Terkait Konsepsi rechterlijk pardon (permaafan hakim) dalam pembaharuan hukum pidana di Indonesia. J urnal Hukum Adigama, Vol.1, (No.1), pp. 125.
Program Studi Magister Ilmu Hukum Fakultas Hukum Universitas Diponegoro 